\title{
A COMPARATIVE STUDY OF SEED GERMINATION AND SEEDLING EMERGENCE OF TWO WILD EDIBLE ALLIUM SPECIES ENDEMIC TO ZAGROS AREAS
}

\author{
WAJED ISSAM HUSSEIN ${ }^{*}$ and DR. SAMI M.A. YOUSSEF ${ }^{* * * * * *}$ \\ *Dept. of Forestry, College of Agricultural Engineering Sciences, University of Duhok, Kurdistan \\ Region-Iraq. \\ ** Dept. Recreation and Ecotourism, College of Agricultural Engineering Sciences, University of \\ Duhok, Kurdistan Region-Iraq. \\ ****AMAP (Botany and Modelling of Plant Architecture and Vegetation), CIRAD / CNRS / INRA / \\ IRD / University of Montpellier, Montpellier-France.
}

(Received: August 5, 2019; Accepted for Publication: October 7, 2019)

\begin{abstract}
Allium L. is one of the largest and most diversified monocotyledonous genera worldwide. These taxa have wide geographical distribution range mainly occurred in the northern hemisphere with an important center of diversity in the Mediterranean and Irano-Anatolian regions. They include an important number of taxa of high economic values (wild edible, cultivated, medicinal, ornamentals, etc.). These geophytes species exhibit diversified adaptation strategies that permit them to persist under harsh environmental conditions. The present experimental study was designed to understanding better the environmental factors that control the natural regeneration of the two wild edible Allium (A. calocephalum and A. notabile) species endemic to Zagros areas via evaluating the effect of different (i) pre-sowing treatments on seed germination rate and (ii) soil depth on seedling emergence timing. The results of the present study confirmed relatively high seed and bulbs viabilities under the different pre-sowing treatments. In general, both Allium species have a relatively similar germination trend (around $80 \%$ without treatments) and seedling emergence (from bulbs at $5 \mathrm{~cm}$ ) patterns. The high rate of seed germination for $A$. calocephalum was found under cold stratification for 1 month and soak in water for 3 days and GA3 $1500 \mathrm{ppm}$ with $83 \%, 86 \%$, and $85 \%$, respectively. The different germination pattern was found for $A$. notabile with $83 \%$, $85 \%, 84 \%$ for soaking water for 2 and 3 days and GA3 $1000 \mathrm{ppm}$, respectively. Whoever, these two threatened species from different taxonomical groups and habitats have different adaptation strategy. $A$. notabile is Mediterranean species exhibiting an optimum seedling emergence in autumn-early winter with summer underground organ dormancy to avoid the hot-dry conditions; While, A. calocephalum is IranoAnatolian species exhibiting an optimum seedling in late winter-early spring permitting it to persist thanks to its avoidance strategy of the harsh winter climatic conditions. The results of this research support the idea that Allium species from different habitats exhibit different seed germination and seedling emergency strategies allowing it to persist. The evidence of this experimental study enriches our understanding of the diversified adaptation strategy of the plants. In this context, further experimental investigations are needed to evaluate the crucial rule of the seed germination ecology and bulbs dormancy strategies on the population dynamic and persistence.
\end{abstract}

KEYWORDS: Geophytes, Allium, adaptation strategy, evolutionary ecology, Zagros, overharvesting, biodiversity conservation\

https://doi.org/10.26682/ajuod.2019.22.2.16

\section{INTRODUCTION}

$\mathbf{T}_{\mathrm{in}}^{\mathrm{h}}$ he genus Allium L. described by Linné in 1753, is one of the largest monocotyledonous genera (Govaerts et al., 2019). This genus includes more than 800 taxa worldwide (Hanelt et al., 1992; Fritsch et al.,
2010). It includes a variable group of species and the debate continues about the taxonomic position of the Allium genus: In early classification, it has been placed under Liliaceae family (e.g. Flora of Iraq according to Wendelbo \& Stuart, 1985) while they were often placed later in the Amaryllidaceae family (e.g. Phillips, 
2010). Thanks to recently phylogenetic studies based on molecular data, they divided the Allium genus into several subgenera belonging to Alliacaea family (Freisen et al., 2006; Fritsch et al., 2010). Increasingly, the recent development in multidisciplinary approach including morphological, karyological, molecular studies adds substantially to our understanding of the taxonomy and evolution in the Allium genus (Hirshengger et al., 2010; Li et al., 2010). In this context, over the past decade there has an important number of the new species and/or new cryptic species of Allium have been described worldwide (Razyfard et al., 2011; Ekşi \& Yildirim, 2019). These taxa are widely distributed thought the northern hemisphere with two important centers of diversity (primary center: Mediterranean Region and IranoAnatolian with CW Asia; secondary center: North America) (Fritsch \& Freisen, 2002; Freisen et al., 2006). These geophytes species naturally occur in the arid/semi-arid and temperate areas within a high habitats' diversity (steppe plains to Alpine zone, thought the foothills) (Hanelt et al., 1992; Kamenetsky, 1996; Kamenetsky \& Rabinowitch, 2006).

Recent evidence suggests that the genus Allium is a good bioindicator showing important bio-structural adaptations correlated with geographical range and environmental conditions (Kamenetsky \& Rabinowitch, 2006). This adaptation evolutionary process permits it to well survive under the Mediterranean type of climate, with its alternation of cool winters and hot dry summers, and thus to guarantee their persistence under harsh environmental conditions (Gutterman et al., 1995; Kamenetsky \& Rabinowitch, 2006). By way of illustration, previous studies have found that the life cycle of Allium taxa is closely related to the climate cycle: the vegetative development stage often stop before the reproductive stage (both fruits and seeds) are fully mature (Fritsch \& Freisen, 2002; Kamenetsky \& Rabinowitch, 2006).
Besides, their flowers usually need an important amount of low/high alternation temperatures while their seed development process is relatively rapid. During the seed formation time, the bulbs start loses their roots and shoot (aboveground organs). A number of studies have confirmed that these geophytes Allium species are well adapted to the severe climatic rhythm of the arid and semi-arid regions when their vegetation period and the root system is reduced and the bulbs enter in dormancy process (Gutterman et al., 1995; Kamenetsky \& Rabinowitch, 2006; Phillips, 2010). Consequently, these geophytes species can avoid the hot dry summer thanks to their underground organs until the more clement environmental condition when the soil moisture reaches an appropriate level to sufficient stimulate the growth (Fritsch \& Freisen, 2002; Kamenetsky \& Rabinowitch, 2006).

The genus Allium includes an important number of taxa of a high economic significance: They include the edible species which cultivated as vegetables (e.g. onion: $A$. cepa; the garlic: $A$. sativum; the leek "kurrat": A. ampeloprasum). Furthermore, numerous other species are used as traditional spices and medicinal plants with high nutritional values. Besides that some Allium species have important ornamentals values cultivated in the parks and home-gardens (e.g. A. giganteum). Due to their high economic value, they are often cultivated regionally or locally (Fritsch and Friesen, 2002; Kamenetsky \& Rabinowitch, 2006) while an important number of wild species are collected and/or overharvested for local use or sold in traditional markets (Kamenetsky \& Rabinowitch, 2006; Firat \& Aziret, 2016). In this context, the overharvesting activities by rural peoples besides the climate change are the leading causes of their population reduction and thus some of the mares seriously threatened by high demand of increased human population growth (Firat \& Aziret, 2016; Véla et al., 2017). 
In recent years, there has been an increasing amount of literature on seed germination ecology, natural regeneration and seedling emergence in both the laboratory and the field (Baskin \& Baskin, 1998; Fenner \& Thompson 2005; Leck et al., 2008). Particularly, the seed germination is an irreversible biological process affecting the population dynamic and persistent (Fenner \& Thompson 2005; Leck et al., 2008). Therefore, understanding the environmental factors that control the natural regeneration of plant species in time and space is decisive for their survival notably for the threatened species and their future biodiversity conservation plans (Leck et al., 2008; Mattana et al., 2010; Youssef et al., 2011; Abdoallahi et al., 2012; Muhamed et al., 2019). In this context, a considerable amount of the literature has been published on seed germination ecology of Allium taxa (Guttermann et al., 1995; Gifre Alonso \& Font Garcia, 2009; Nematollah et al., 2011). Data from the previous studies have indicated that the pre-sowing treatments can increase / decrease the seed germination rate of the Allium taxa and the results are mainly depend on the biological species target, their evolutionary life history and the pre-sowing treatments used (Guttermann et al., 1995; Baskin \& Baskin, 1998; Fenner \& Thompson 2005; Phillips, 2010; Winiarczyk et al., 2014): For example, Nematollah et al., (2011) found that the stratification treatments significantly improved the germination rate of the endemic Persian shallot $A$. hirtifolium boiss. In addition, Kamenetsky \& Gutterman (2000) clearly showed that the temperature is a main environmental factor affecting the seed germination rate of some Allium taxa in an arid zone of C Asia while Gutterman et al. (1995) reported that there is no difference between germination rate of $A$. rothii in light and dark. Contrariwise, Gifre Alonso \& Font Garcia (2009) showed that the darkness significantly accelerated the germination rate of two Allium sect. Allium in the Iberian Peninsula. Others environmental factors such as $\mathrm{NaC} 1$ concentration decreased the germination rate of A. truncatum (Feinbr.) Kollman \& D. Zohary naturally occurred in the Negev Desert highlands (Gutterman et al., 1995).

Irano-Anatolian hotspot including Zagros territories is one of the high biological diversity values worldwide (Mittermeier et al., 2004) as well as an important diversity center for Allium Genus (Fritsch \& Freisen, 2002). By way of illustration, there are more than 200 Allium taxa naturally occur in Turkey (Kaya, 2014), 120 in Iran (Freisen et al., 2006; Fritsch \& Abbasi, 2008) and 40 in Iraq (Wendelbo \& Stuart, 1985). Furthermore, these Zagrosian areas include an important number of rare, endemic and threatened Allium species (Razyfard et al., 2010; Kaya, 2014). In addition, these Zagros areas including the Mesopotamian fertile plains are under anthropogenic activities (cultivation, grazing, etc.) for millennia. In this anthropogenic circumstance, previous studies have found that the overharvesting of wild edible Allium from their natural habitats has induced an obvious decline in their population and they exposure to the extinction risk (Firat \& Aziret, 2016; Véla et al., 2017). In this context, both wild edible and endemic Allium species to Zagros area (A. calocephalum Wendelbo and A. notabile Feinbrun) are seriously threatened by the overharvesting activities (Firat \& Aziret, 2016; Véla et al., 2017). In addition, our understanding of their seed germination ecology and propagation are inexistent, and in need of additional scientific investigations. Therefore, the present experimental study focused on the development of a protocol for their propagation by both seeds and bulbs. Particularly, this research study seeks to (i) provide a new contribution in terms of the effect of some presowing treatments on the seed germination rate and bulbs propagation of two endemic Allium to Zagros areas; (ii) examine the seedling emergence timing related to seed sowing pre- 
treatment. From economic botany perspectives, the results of this field experiment study will provide a solid database for both governmental and private nursery sectors on seed germination and seedling emergence timing of Allium taxa. Indeed, in the Kurdistan region, this agro-socioeconomic initiative "cultivation of wild edible Allium has never been addressed. Therefore, this field cultivation experiment which could provide a source of income to many small farmers in a rather low investment as well as contributing to nature protection by minimizing clipping from the wild.

\section{MATERIALS AND METHODS Experimental Site Study}

For this research, a germination experiment was carried out at the Forestry nursery field of College of Agricultural Engineering Sciences, University of Duhok, Kurdistan Region of Iraq. The geolocation is: Latitude: 36.860396; Longitude: 42.868776; Altitude $480 \mathrm{~m}$ above sea level (asl). The scientific experiment started on 24 October 2018 to study the potential propagation of A.calocephalum and A.notabile by both seeds and bulbs. The seed and bulbs cultivation experiment were situated in Zagrosian semi-arid region (Peel et al., 2007; Youssef et al., 2019). From the bioclimatic standpoint, this research site study has XeroThermo-Mediterranean bioclimate: Annual rainfall of 2018 was $798 \mathrm{~mm}$; Mean of temperature was $19.4^{\circ} \mathrm{C}$; Winter MIN mean daily around $0^{\circ} \mathrm{C}$ while the MAX is under $40^{\circ} \mathrm{C}$ (Source: Agro-Meteorological of College of Agricultural Engineering Sciences, University of Duhok). Globally, the precipitation season starts on October-November and ended on May, with at least four months without rainfall (Youssef et al., 2019).

\section{Seeds Collection And Pre-Sowing Treatments}

In this research study, the seeds of two endemic wild Allium to Zagros areas (A. calocephalum and A. notabile) were used in the field experiment. We directly collected from the field, the fully matured seeds and bulbous with a vigorous and healthy appearance growing.
Immature and damaged seeds were eliminated while the mature dry seeds were stored in glass jars and the bulbs stored in a dark environment at room temperature (around $20^{\circ} \mathrm{C}$ ) until the beginning of the germination experiment. The seeds and bulbs of $A$. calocephalum were collected in June 2018 from the north aspect of Gara Mountain (Hariké Village, Deralok District: Latitude: 37.0136820; Longitude: 43.6859840; elevation $1096 \mathrm{~m}$ asl). While the seeds and bulbs of A. notabile were collected in July 2018 from south aspect of Gara Mountain (above Bané village: Latitude: 36.9147300; Longitude: 43.2359380; elevation $967 \mathrm{~m}$ asl).

In this experimental research for both Allium species, different pre-sowing treatments were tested to assess the best treatment in term of germination success rate. Which were: untreated seeds which used as the control; hot water $\left(60^{\circ} \mathrm{C}\right)$ with three categories $(5,10$ and 15 minutes soak time); normal "distilled" water $\left(15-20^{\circ} \mathrm{C}\right)$ with three soak time categories $(1,2$ and 3 days soaking); Gibberellic Acid (GA3) with three concentration $500 \mathrm{ppm}, 1000 \mathrm{ppm}$ and $1500 \mathrm{ppm}$ were soaked in GA3, for 5 minute; Finally, the cold stratification, moisturized seeds with distilled water were placed in a sealed plastic box in a refrigerator at a temperature below $+5^{\circ} \mathrm{C}$, for 30,60 and 90 days under constant light conditions. After presowing treatment, the seeds were planted in medium pots (Diameter $13 \times 10 \mathrm{~cm}$ height) containing a mixture of sandy soil, field soil and Peat-moss (1:1:1). A 100 seed lot issued were selected from each pre-sowing treatment per Allium species. These 100 seed lots were then divided into four replication and put in four different pots "four replication"; Then, 25 seed per pot were cultivated at around $1 \mathrm{~cm}$ soil depth according to the method of Krussmann (1981). A total of 1300 seeds were cultivated for each Allium species. The pots (104 in total) had been irrigated once per week, if needed, during the complete period of the germination experiment. On other hands, the bulbs were cultivated directly in the soil according to different soil depth $(5,10,15$ and $20 \mathrm{~cm})$ to test the effect of 
the soil depth on the seedling emergence of both endemic Allium species. The bulbs were cultivated in rows (4 m long; $95 \mathrm{~cm}$ width; 10 $\mathrm{cm}$ space between rows) in sowing media madeup from a mixture of sandy soil, field soil and Peat-moss (1:1:1). There were 16 quadrate plots used for four soil depth $(5,10,15$ and $20 \mathrm{~cm})$ with four replications for each soil depth and 5 bulbs in each replicate were planted. This germination experiment was arranged in nursery according to a completely randomized design by dividing 1300 seeds into four replication groups (4 replications $\times 25$ seeds) for each treatment used in this study. The observation of seedling emergence and measurement of germination rate were carried out weekly during the research experiment (from 24 October 2018 to 30 June 2019). Seedling emergence was accounted when the shoot of the seedling came around $1 \mathrm{~cm}$ above the ground.

For statistically analyzing the seeds germination rate and the seedling emergence, the data have been arranged in an excel sheet ( $($ ) Microsoft office); and then the data was treated by the analysis of variance (ANOVA) and Student-Newman-Keuls test to do the comparison two-by-two using R-program ( $\mathrm{R}$ Development Core Team, 2019)

\section{RESULTS AND DISCUSSION Allium calocephalum seed germination ecology}

In-plant life cycle, seeds are important structures to maintain species survival where their germinations are often related to specific environmental conditions (Fenner \& Thompson, 2005; Baskin \& Baskin, 1998; Leck et al., 2008; Willis et al., 2014). In this context, the seeds of many species do not germinate due to temporary dormancy mechanisms that may be broken as a result of the exposure of the seed to environmental factors during an appropriate period of time (Baskin \& Baskin, 1998; Donhoue, 2005; Hoyle et al., 2015). Concerning A. calocephalum, the results obtained from experimental data are shown in Fig. 1. These results were clearly confirmed a high percentage of viable seeds where they germinated with different rate degree for all pre-sowing treatments. In spite of the germination rate and seedling emergence timing responded differently to pre-sowing treatments, whoever, the variance analysis and Student-Newman-Keuls test have not shown significant differences between the treatments $(\mathrm{P}$ value $>0.05)$. These insignificant differences can be explained in part by the high inter and intra variations of the pre-sowing treatments. Indeed, interestingly, the germination rate was $80 \%$ without any treatment "control". The findings of the present study are consistent with those of Gifre Alonso \& Font Garcia (2009) and Guttermann et al. (1995) who found similar germination results (around 80\%) for Allium species. As shown in Fig. 1, several pre-sowing treatments have negative effect on seed germination (lower than the control): They were hot water $(5,10$ and 15 minutes with germination rate: $77 \%, 74 \%$ and $73 \%$ respectively), seed soaking for one day (germination rate: 76\%), stratification (for 2 and 3 months with $77 \%$ germination rate for the both treatment time) and GA3 with concentration 500 ppm (germination rate: $78 \%$ ). A possible explanation for this reduction germination rate is that the Allium seed coat is relatively thin (Celep et al., 2012) and thus some pre-sowing treatment like hot water leads to seed embryo death (Baskin \& Baskin, 1998). On the other side, some other pre-sowing treatments have increased the germination rate of $A$. calocephalum. By way of illustration, the germination rate for immersion of seeds in water for 2 days and 3 days, stratification for 1 month and using GA3 with $1500 \mathrm{ppm}$ were $81 \%, 86 \%$, 83 and $85 \%$ respectively. This increasing seed germination rate can be explained in part by the micro-environmental conditions where $A$. calocepahalum naturally occur (middle to high forest zone of Zagros mountains between 1200 to $1800 \mathrm{~m}$ asl where the climatic conditions are characterized by a cold-humid winter). Consequently, the stratification of its seed for one month, GA3 $1500 \mathrm{ppm}$ and the soaking time to one day stimulate the initiating of the embryo 
metabolism process. These results accord with other classical earlier studies on seed germination ecology topic (Baskin \& Baskin, 1998; Fenner \& Thompson, 2005; Phillips, 2010). For example, Nematollah et al. (2011) were clearly showed that the stratification time after the sixth improved the germination rate of the threatened endemic Persian shallot $A$. hirtifolium

boiss.

\section{Allium calocephalum}

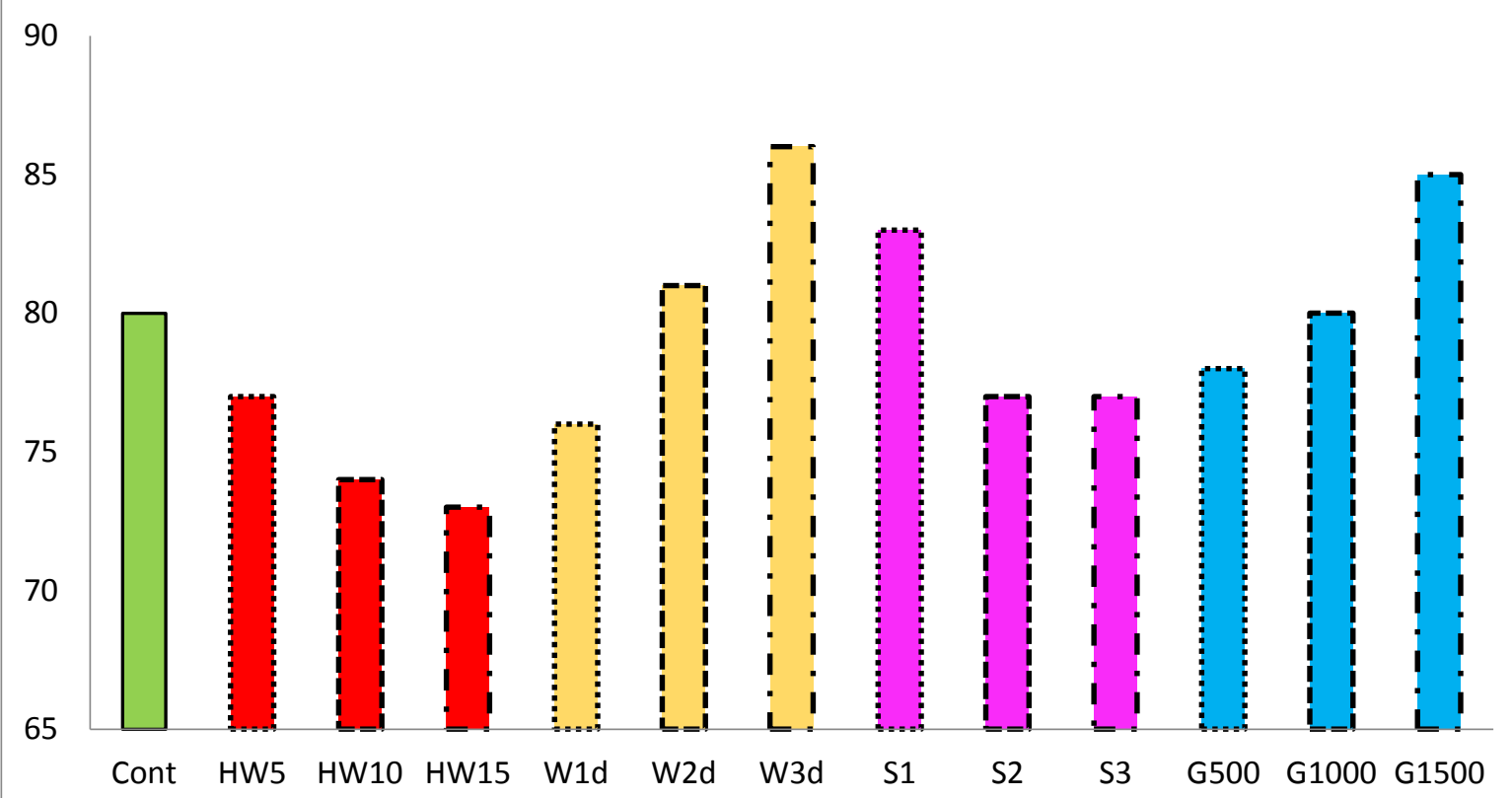

Fig. (1): A. calocephalum seed germination rate under various pre-sowing treatments, Cont $=$ Control, HW5 = Hot water at $5 \mathrm{~min}, \mathrm{HW} 10=$ Hot water at $10 \mathrm{~min}, \mathrm{HW} 15=$ Hot water at $15 \mathrm{~min}, \mathrm{~W} 1=$ Seed in water 1 day, W2 $=$ Seed in water 2 days, W3 = Seed in water 3 days, S1 = Stratification 1 month, S2 = Stratification 2 month, S3 $=$ Stratification 3 month, G500 = GA3 500 ppm, G1000 = GA3 1000 ppm, G1500 = GA3 1500 ppm.

It is apparent from Fig. 2 that there is a clear trend of seedling emergence in late winter-early spring. In fact, the first seedling emergence started in January while it obtained the optima seedling emergence from February to March. This optima germination rate achieved where the mean temperature was 10 to $25 \mathrm{C}^{\circ}$ in nursery condition. These findings seem to be consistent with an earlier study in seed germination ecology of Allium species, which showed that they fast germinate at 10 to $20 \mathrm{C}^{\circ}$ (Gutterman et al., 1995). Interestingly, this germination strategy of $A$. calocephalum at the right time of the year "late winter-early spring" when temperatures reach a daily 10-25 $\mathrm{C}^{\circ}$ which will give the seedlings a higher chance of survival under the harsh and unpredictable Irano-Anatolian environmental conditions (Gutterman et al., 1995; Piotto\& Di Nio, 2003; Mahdi et al., 2018a\&b). 


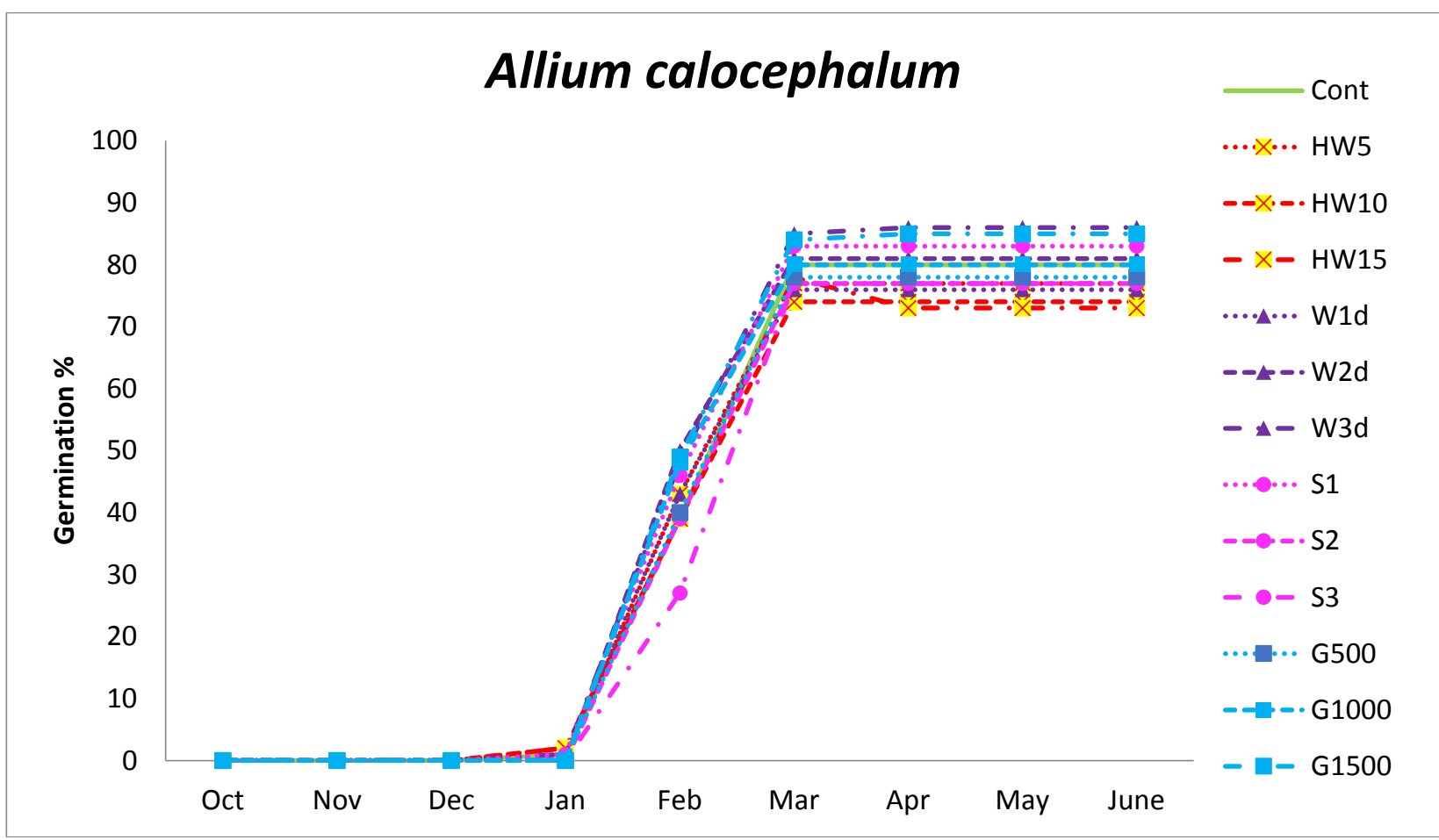

Fig. (2): A. calocephalum seedling leek emergence, Cont $=$ Control, HW5 = Hot water at 5 min, HW10 = Hot water at $10 \mathrm{~min}, \mathrm{HW} 15=$ Hot water at $15 \mathrm{~min}, \mathrm{~W} 1=$ Seed in water 1 day, W2 = Seed in water 2 days, W3 = Seed in water 3 days, S1 = Stratification 1 month, S2 = Stratification 2 month, S3 = Stratification 3 month, G500 = GA3 500 ppm, G1000 = GA3 1000 ppm, G1500 = GA3 1500 ppm.

\section{Allium notabile seed germination ecology}

It is a wild leek endemic to the southern slopes of the Zagros Mountains (Zawita-Atrush in Duhok governorate and Qara-Dagh in Sulaymaniya governorate), Kurdistan Region of Iraq (Wendelbo \& Stuart, 1985). This edible leek species is most probably harvested by rural people in confusion with several others wild leek species of Allium sect. Allium (Véla et al., 2017). From agro-socio-economic perspectives, the ethnodomestication initiative of this wild edible leek will be considerably contribute to minimizing its collection from natural habitat. In this context, the results of this seed germination study will provide a significant source of information for its cultivation and semidomestication. From the experimental data in Figure 3, it is apparent that it has a relatively good germination rate around $78 \%$ without any pre-sowing treatments. This result of germination is similar to the previous wild garlic (A. calocephalum) as well as accords with earlier studies showed that the seeds of Allium species have a high viability germination rate
(Guttermann et al., 1995; Gifre Alonso \& Font Garcia, 2009). However, some pre-sowing treatments decreased the germination rate: By way of illustration, for the stratification with 1,2 and three months the germination rate were $72 \%, 74 \%$, and $72 \%$ respectively. This observed decreasing was expected and suggests that it prefer clement climatic conditions. A possible explanation for this might be that it occurs in rocky dry grasslands in steppic open Oak and Pine forest under Mediterranean bio-climate (Véla et al., 2017). On the other hand, the GA3 with the three concentration level $(500,1000$, $1500 \mathrm{ppm}$ ) and soaking seeds in water for 2 and 3 days increase the germination rate. The GA3 results differ from Nematoallah et al. (2011) indicate the GA3 concentration did not affect the germination rate, but they are broadly consistent with earlier seed germination studies (Baskin \& Baskin; 1998). While it seems possible that the results of the seed soaking for 2 and 3 days lead the water to enter inside the seeds and thus help the development of the embryo. 


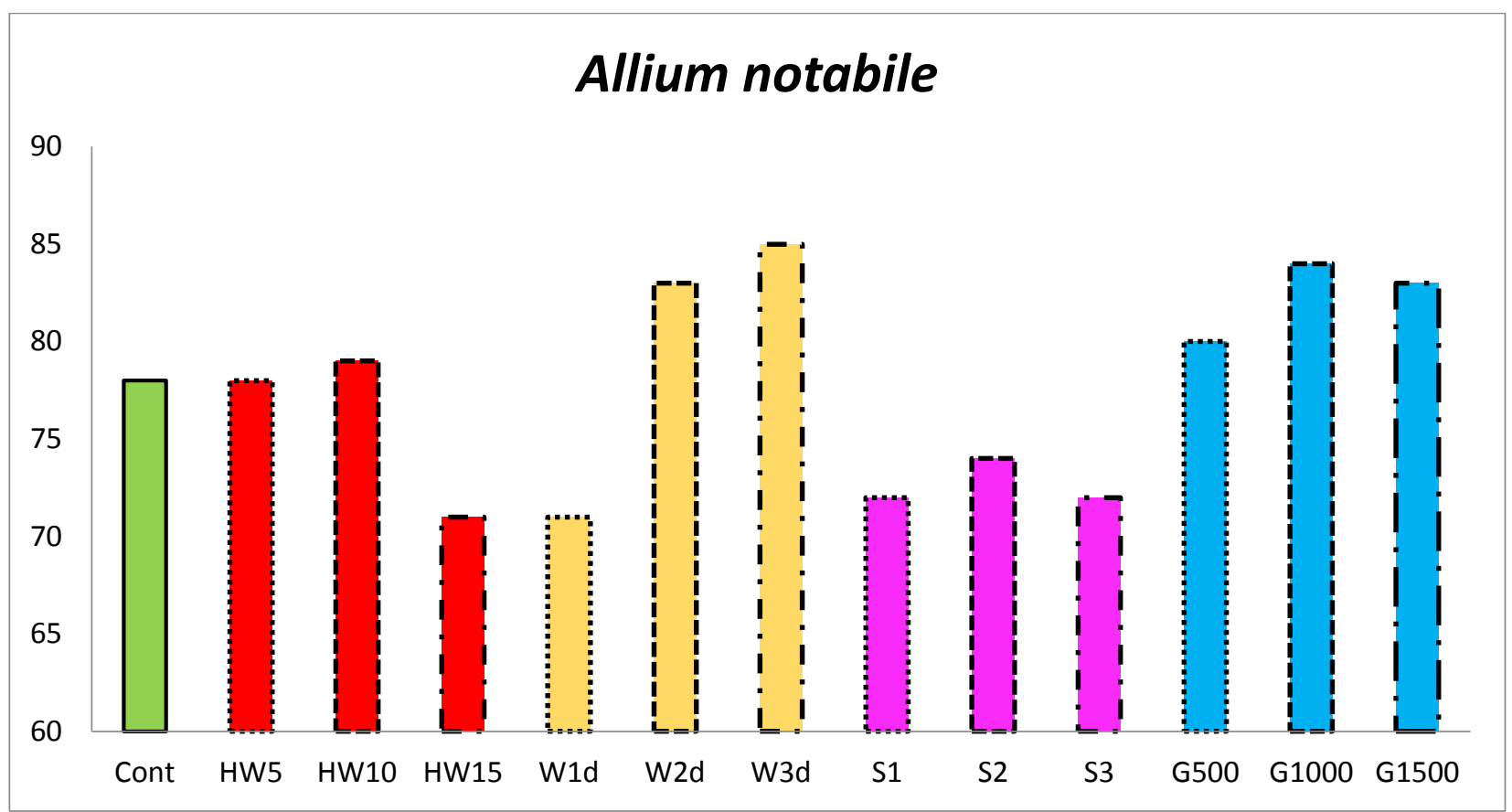

Fig. (3): A. notabile seed germination rate under various treatments, Cont $=$ Control, HW5 = Hot water at 5 min, HW10 = Hot water at $10 \mathrm{~min}, \mathrm{HW} 15=$ Hot water at $15 \mathrm{~min}, \mathrm{~W} 1=$ Seed in water 1 day, W2 = Seed in water 2 days, W3 = Seed in water 3 days, S1 = Stratification 1 month, S2 = Stratification 2 month, S3 = Stratification 3 month, G500 = GA3 500 ppm, G1000 = GA3 1000 ppm, G1500 = GA3 1500 ppm.

In the current study, the seedling emergence timing of $A$. notabile provided a significant adaptation strategy to Mediterranean bio-climate. The results, as shown in Fig. 4, indicate that it has autumn-early winter seedling emergence. For example, the first seedlings start to emerge in November with an optimum seedling emergence on January-February. Furthermore, its seeds relatively germinate quickly (2-3 weeks) where the mean temperature was 15 to $25 \mathrm{C}^{\circ}$ in nursery condition. In fact, this Mediterranean wild leek germinates in autumn, like most of the annual Mediterranean species after the first autumnal rainfall (Thompson, 2005; Youssef et al., 2011). This autumnal fast-growing adaptation strategy will likely give the seedlings to benefits from Mediterranean winter clemency condition and thus a higher chance of survival the next year. These findings accord with most earlier studies in seed germination ecology of Mediterranean plant species (Gutterman et al., 1995; Leck et al., 2008). 


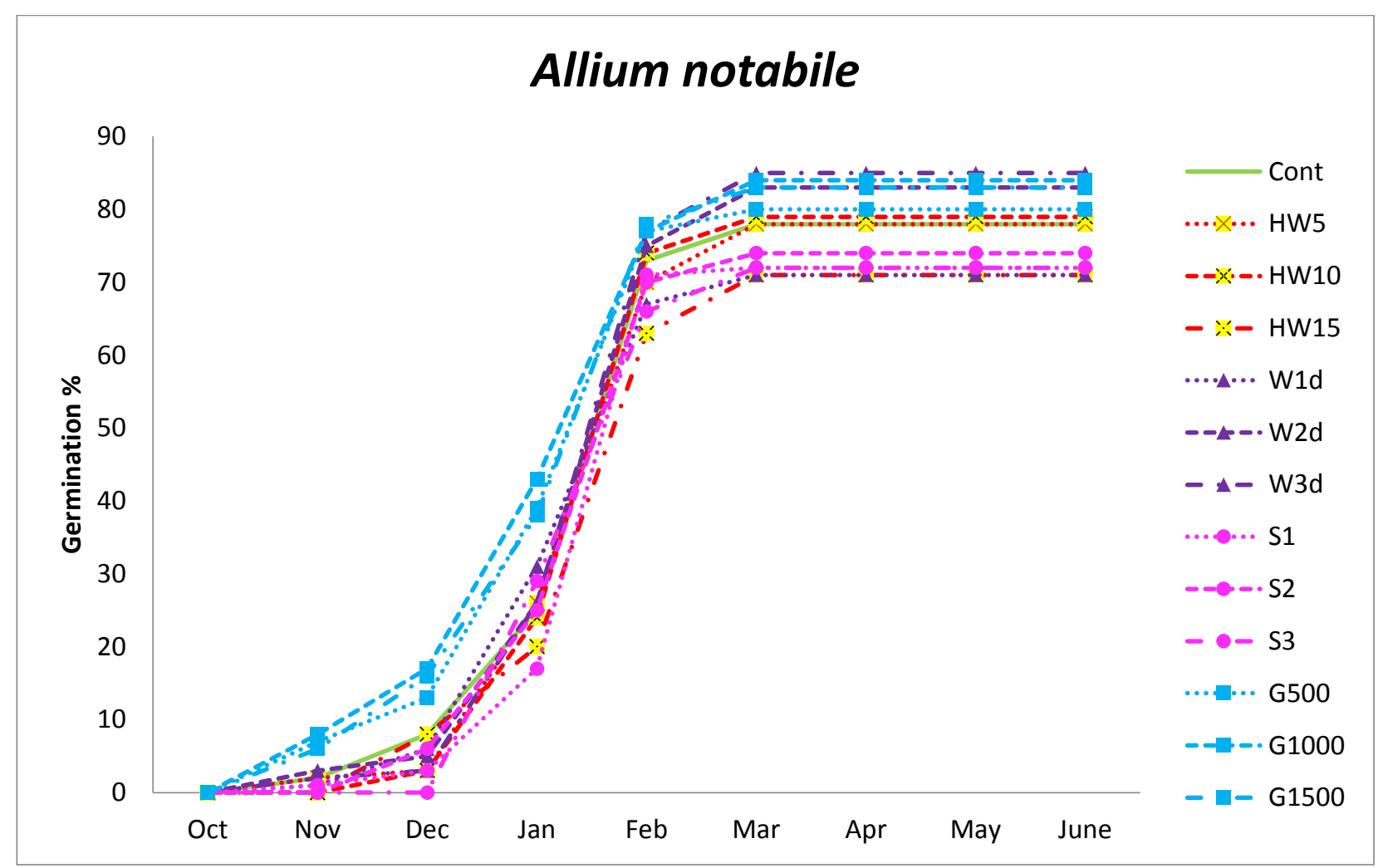

Fig. (4): A. notabile seedling leek emergence, Cont $=$ Control, HW5 = Hot water at $5 \mathrm{~min}, \mathrm{HW} 10=$ Hot water at $10 \mathrm{~min}, \mathrm{HW} 15=$ Hot water at $15 \mathrm{~min}, \mathrm{~W} 1=$ Seed in water 1 day, W2 = Seed in water 2 days, W3 = Seed in water 3 days, S1 = Stratification 1 month, S2 = Stratification 2 month, S3 = Stratification 3 month, G500= GA3 500 ppm, G1000 = GA3 1000 ppm, G1500 = GA3 1500 ppm.

\section{Bulbous Cultivation And Soil Depth}

In recent years, seedling emergence is known to be related by climatic, intrinsic biological and soil depth factors (Holm 1972; Baskin \& Baskin, 1998; Fenner \& Thompson, 2005; Leck et al., 2008). Unfortunately, the biological reasons for soil depth inhibition have not yet been fully understood due to a complex biological evolutionary process. Whoever, globally, previous studies suggest that the soil depth inhibition is mainly due to decreasing of light penetration, thermal fluctuation and gas exchange (Barkham, 1980; Roberts \& Totterdell, 1981; Benvenuti et al., 2001). Furthermore, recent evidence suggests that the bulbs planting depth significantly affect the growth, yield and emergence success of the geophytes species (Alam et al., 2013; Marcinek et al., 2013). In this context and from ethnodomestication perspective, it is therefore meaningful to acquire maximum knowledge on wild edible bulbs cultivation and their emergence ability according to various soil depths. Interestingly, high seedling emergence was found when the bulbs cultivate at $5 \mathrm{~cm}$ for A. calocephalum and at 5 and $10 \mathrm{~cm}$ for $A$. notabile (Fig. 5). These results support previous research into this brain area which links seedling emergence and soil depth (Benvenuti et al., 2001; Alam et al., 2013) and confirms the general rule that the plant seeds and bulbs cultivate at twice/three times as deep in the soil as their size. At $15 \mathrm{~cm}$ soil depth, both edible bulbous species have similar seedling emergence decreasing pattern (with 35 and 40 seedlings for A. calocephalumand A. notabile, respectively). The most striking result to emerge from the data is that there is any seedling emergence at $20 \mathrm{~cm}$ for both Allium species. This general pattern of decreasing seedling emergence with increasing soil depth has been demonstrated by earlier research studies (Benvenuti et al., 2001; Alam et al., 2013). This observed seedling emergence pattern which is inversely correlated with burial depth could be attributed to lack sufficient amount of oxygen, light and/or the bulbs reserve 
capacity (Benvenuti et al., 2001; Kamenetsky et al., 2004; Alam et al., 2013). For example, Barkham (1980) reported that the bulbs of Narcisus species planted at shallower depths (less $5 \mathrm{~cm}$ ) produced more vegetative daughters than did deeper planted bulbs (more than $10 \mathrm{~cm}$ depth).

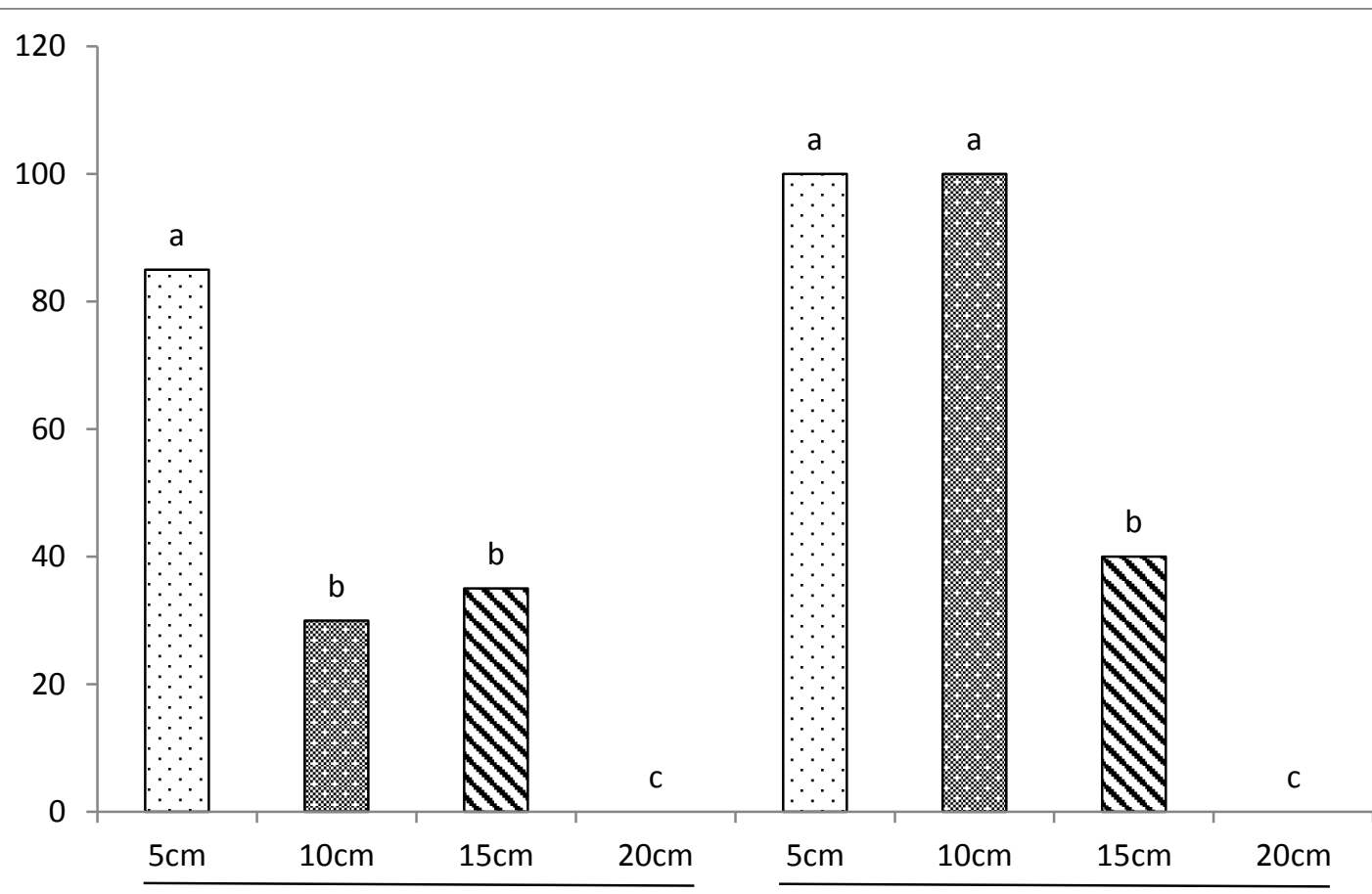

A. calocephalum

A. notabile

Fig. (5): Allium bulbs emergence at a different soil depth. The code a,b,c, indicate the differences between the soil depth according to Student-Newman-Keuls test at level 0.05.

\section{Allium Seedling Emergence Strategy}

It is becoming increasingly difficult to ignore the diversity of plant adaptations to their natural environment. In recent years, these divers adaptation strategies have been broadly studied at multiple scales and scientific discipline (from gene to ecosystem and from molecular biology to biogeography) (Grime, 2006; Leck et al., 2008; Hoyle et al., 2015; Volaire, 2018). Recently, knowledge of plant adaptation strategy has aroused increasing interest in the context of biodiversity conservation. Geophytes species have some kind of underground storage organs (ex: bulb, tuber, etc.) that grow naturally at some depth in the soil, and each year they renew their reproductive organs. Allium species as the most diversify geophytes taxa group, their bulbous have various dormancy disputative traits that allow it to maximize survival success by increasing the vegetative growth in the most suitable season (Kamenetsky \& Rabinowitch,
2006; Phillips, 2010). Thanks to their unique life-form "bulbs" the follow the drought avoidance strategies: The reserve in their bulbous provides a precious resource allowing the Allium species to persist the unfavorable climatic season (hot and dry summer) by entering dormant phase until soil moisture and temperature reach appropriate level to stimulate the vegetative growth (Fritsch \& Freisen, 2002; Kamenetsky \& Rabinowitch, 2006; Phillips, 2010). Interestingly, from the data of Figure 6 $\mathrm{a} \& \mathrm{~b}$, it is apparent that the two wild edible Allium species have different seedling emergence strategy: Indeed, A. notabile as Mediterranean species, and its optimum emergence from both seeds and bulbs is in autumn-early winter. This early emergence most likely enables the bulbs to develop strong roots and vegetative growth which in tour will support the flowering phase in the summer. This finding supports the Mediterranean adaptative plant 
strategies with summer dormancy to avoid hotdry conditions. Consequently, the plant growth begins in autumn-early winter, the vegetative development continues through the clement winter and spring while the flowers occur in late spring-summer, and then underground storage organ enters in dormancy to avoid drought (Fritsch \&Freisen, 2002; Kamenetsky and Rabinowitch 2006). On the other hand, A. calocephalum from section Melanocrommyum., is a real Irano-Anatolian species, and its optimum emergence according to our results is in late winter-early spring enable it to avoid the harsh winter climatic conditions (snow and frost) and thus it will give their seedlings a higher chance to survive. This finding corroborates the Irano-Anatolian adaptative plant strategies by avoidance of the harsh climatic conditions (cold winter and dry-hot summer) where the aboveground growth rate is maximum reduced while the fall development is achieved in spring
(Pistrick 1992; Fritsch \& Freisen, 2002; Kamenetsky \& Rabinowitch, 2006). From ethnobotanical standpoint, a considerable wild edible plant species are collected for home consumption and/or sold in traditional markets (Hadjichambis et al., 2008; Schulp et al., 2014; Youssef et al. 2017). These wild edible plants have important economic value and are often cultivated "semi-domesticated" regionally or locally (Hanelt, 2001; Hadjichambis et al., 2008). Under this permanent overharvesting pressure, their natural populations are seriously threatened and thus exposure to the extinction risk. In the new global economy approach, it is becoming increasingly difficult to ignore the environmental factors controlling the natural regeneration of threatened wild edible species. In this dramatical circumstance, investigating the seed germination ecology of the two wild edible Allium species has become vital for their future biodiversity conservation strategies.

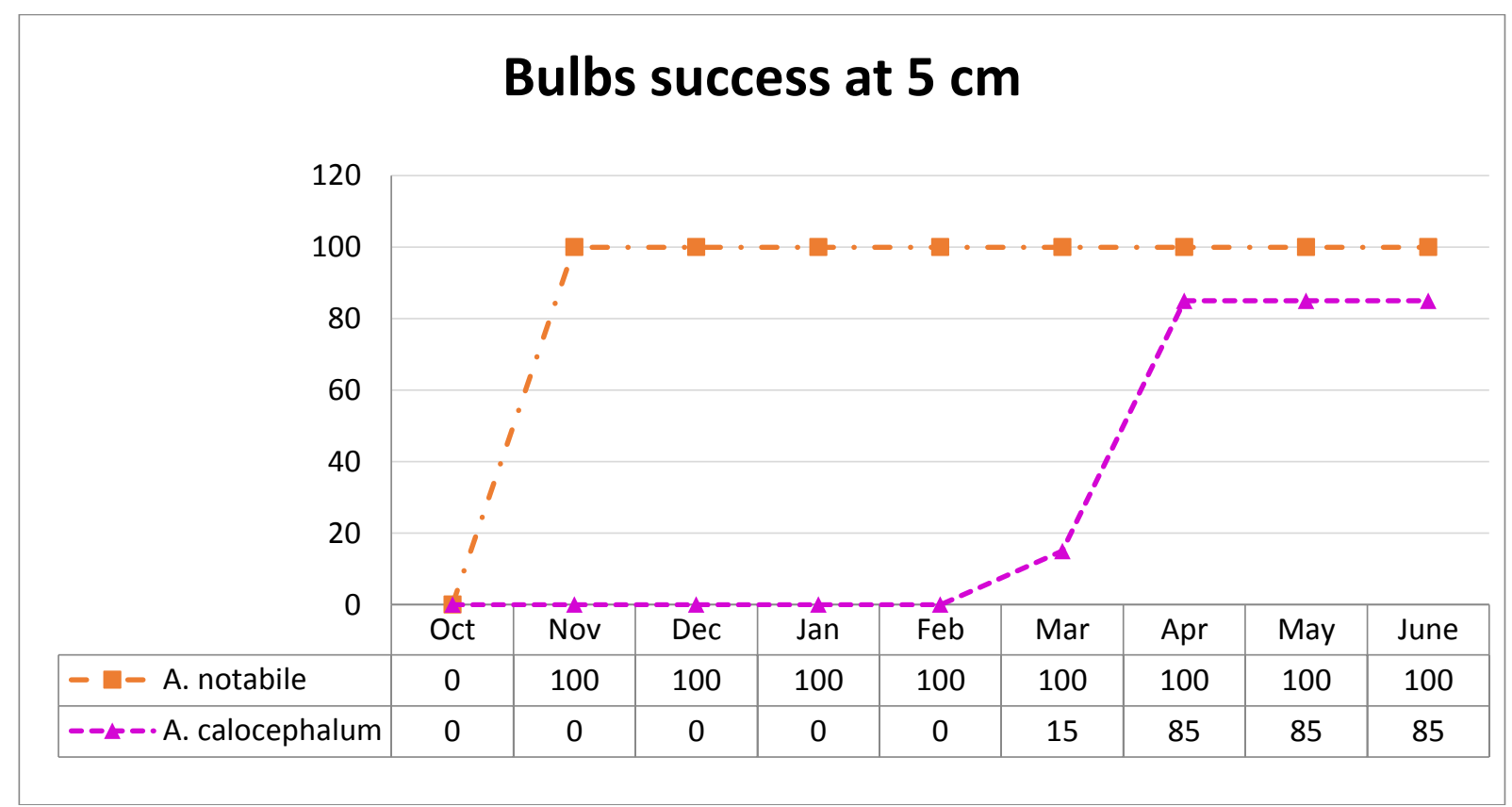

Fig. (6a): Bulbs emergence rate at $5 \mathrm{~cm}$ in both species 


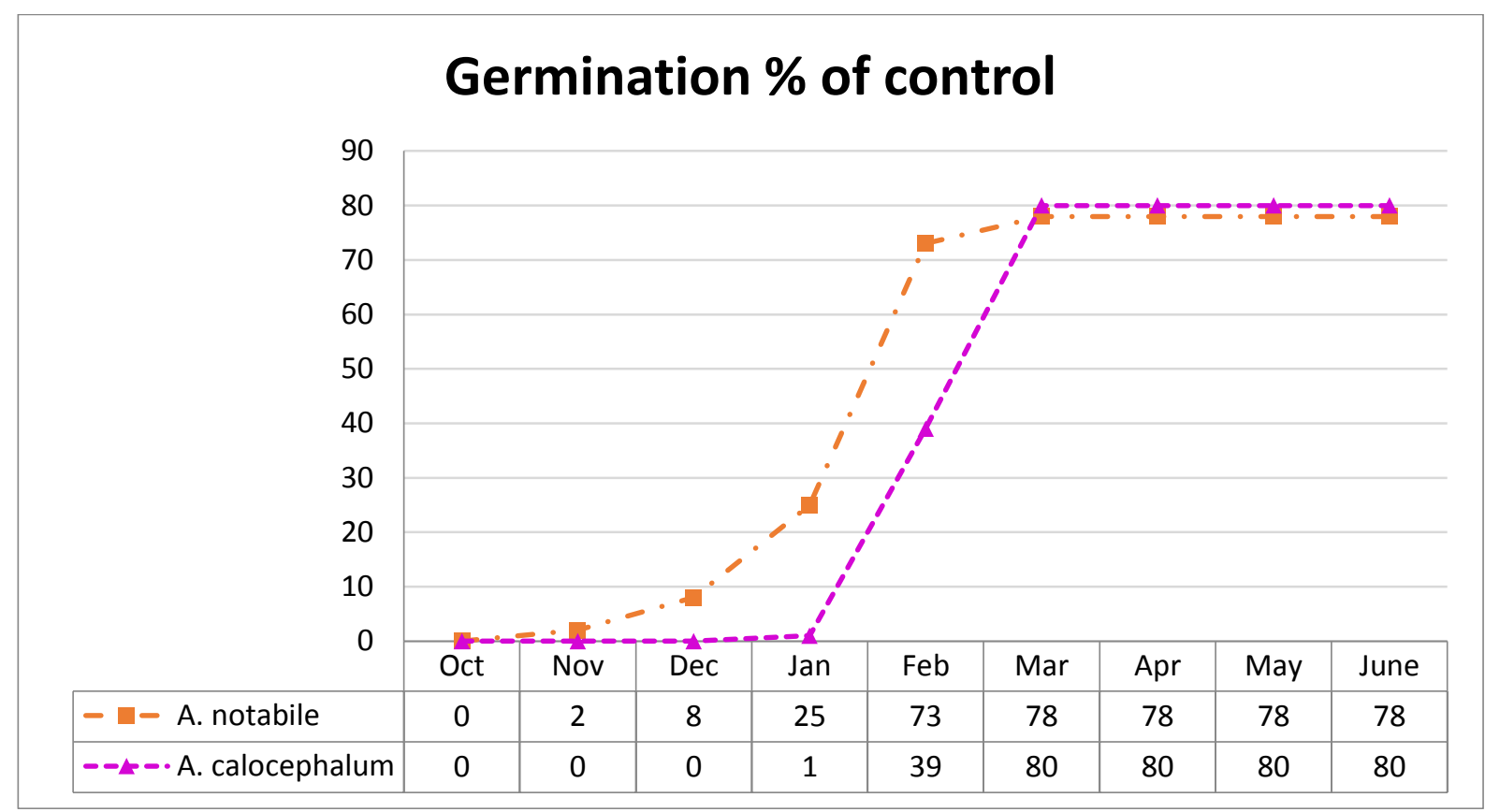

Fig. (6b): Seed germination rate of control in both species

\section{CONCLUSION}

This paper has given an account of the seed germination ecology and seedling emergence of two wild edible Allium species endemic to Zagros areas. This comparative seedling emergence study of two Allium species, one inhabiting foothill under Mediterranean climate and the other mountains under Irano-Anatolian climate, attribute to a better understanding of the adaptation mechanisms of these species under harsh and unpredictable Zagros conditions. The both Allium species have a relatively similar pattern with good germination rate (around 80\% without treatments) and seedling emergence from bulbs at $5 \mathrm{~cm}$. Whoever, they differ in their adaptation strategy (emergence timing strategy) to better tolerant/avoid the unfavorable germination and seedling niche. A possible explanation of this different adaptative strategy might be that these two Allium species belong to different taxonomical groups and occurs in different habitats. Therefore, the findings of this research enhance better our understanding of the seed germination ecology and seedling emergency strategies and it will be interesting to assess the effect of overharvesting in their population dynamics and thus their conservation status.

\section{REFERENCES}

Abdollahi, J., Ebrahimi, M., Ramshini, H. A., Jaafari, A. A., Eftekhari, M., Mansouri, Y. S., \& Goharrizi, M. A. S. B. (2012). Seed germination as the major conservation issue of endemic Iranian salvia species. Journal of Medicinal Plants Research, 6(1), 37-46.

Alam, A., Iqbal, M., \& Vats, S. (2013). Cultivation of Some overlooked Bulbous Ornamentals-A review on its commercial viability. Report and opinion, 5, 9-34.

Baskin, C. C., \& Baskin, J. M. (1998). Seeds: ecology, biogeography, and, evolution of dormancy and germination. Elsevier.

Benvenuti, S., Macchia, M., \&Miele, S. (2001). Quantitative analysis of emergence of seedlings from buried weed seeds with increasing soil depth. Weed Science, 49(4), 528-535.

Barkham, J. P. (1980). Population dynamics of the wild daffodil (Narcissus pseudonarcissus): I. clonal growth, seed reproduction, mortality and the effects of density. The Journal of Ecology, 607-633. 
Celep, F., Koyuncu, M., Fritsch, R. M., Kahraman, A., \& Doğan, M. (2012). Taxonomic importance of seed morphology in Allium (Amaryllidaceae). Systematic Botany, 37(4), 893-912.

Donohue, K. (2005). Seeds and seasons: interpreting germination timing in the field. Seed Science Research, 15(3), 175-187.

Ekşi, G., \&Yildirim, H. (2019). Allium yamadagensis (Amaryllidaceae) a new species from Turkey. Phytotaxa, 400(1), 31-36.

Fenner, M., \& Thompson, K. (2005). The ecology of seeds. Cambridge University Press.

Firat, M. and Aziret, A. 2016. Edible Allium L. species that are sold as fresh vegetables in public bazaars of Hakkâri province and its surroundings in Turkey. Acta BiologicaTurica 29(1): 14-19.

Friesen, N., Fritsch, R. M., \&Blattner, F. R. (2006). Phylogeny and new intrageneric classification of Allium (Alliaceae) based on nuclear ribosomal DNA ITS sequences. Aliso: A Journal of Systematic and Evolutionary Botany, 22(1), 372-395.

Fritsch, R. M., \& Abbasi, M. (2008). New taxa and other contributions to the taxonomy of Allium L. (Alliaceae) in Iran.

Fritsch, R. M., \& Friesen, N. (2002). Evolution, domestication and taxonomy. Allium crop science: recent advances, 5-30.

Fritsch, R. M., Blattner, F. R., \& Gurushidze, M. (2010). New classification of Allium L. subg. Melanocrommyum (Webb \& Berthel.) Rouy (Alliaceae) based on molecular and morphological characters. Phyton (Horn), 49(2), 145-220.

Gifre Alonso, M. C., \& Font Garcia, J. (2009). A comparative study of germination strategies of two species of genus Allium sect. Allium. A 'Màster en Medi Ambient. Itinerari de Biologia Ambiental: biodiversitat i conservació'. Girona: Universitat.
Govaerts, R., Kington S., Friesen N., Fritsch R., Snijman D.A., Marcucci R., SilverstoneSopkin P.A., Brullo S. (2019). World Checklist of Amaryllidaceae. Facilitated by the Royal Botanic Gardens, Kew. Published on the Internet; http://wcsp.science.kew.org/ Retrieved 27 July 2019.

Grime, J. P. (2006). Plant strategies, vegetation processes, and ecosystem properties. John Wiley \& Sons.

Gutterman, Y., Kamenetsky, R., \& Van Rooyen, M. (1995). A comparative study of seed germination of two Allium species from different habitats in the Negev Desert highlands. Journal of Arid Environments, 29(3), 305-315.

Hadjichambis, A. C., Paraskeva-Hadjichambi, D., Della, A., Elena Giusti, M., De Pasquale, C., Lenzarini, C., Censorii, E., Gonzales-Tejero M.R., Sanchez-Rojas, C.P., Ramiro-Gutierrez, J.M., Skoula, M., Johnson, C., Sarpaki, A., Hmamouchi, M., Jorhi, S., El-Demerdash, M., El-Zayat, M., \& Pieroni, A. (2008). Wild and semi-domesticated food plant consumption in seven circum-Mediterranean areas. International Journal of Food Sciences and Nutrition, 59(5), 383-414.

Hanelt, P., Schultze-Motel, J., Fritsch, R., Kruse, J., Maass, H. I., Ohle, H., \& Pistrick, K. (1992). Infrageneric grouping of Allium -the Gatersleben approach (No. RESEARCH). Institute of Plant Genetics and Crop Plant Research.

Hirschegger, P., Jakše, J., Trontelj, P., \&Bohanec, B. (2010). Origins of Allium ampeloprasum horticultural groups and a molecular phylogeny of the section Allium (Allium: Alliaceae). Molecular Phylogenetics and Evolution, 54(2), 488-497.

Holm, R. E. (1972). Volatile metabolites controlling germination in buried weed seeds. Plant physiology, 50(2), 293-297.

Hoyle, G. L., Steadman, K. J., Good, R. B., McIntosh, E. J., Galea, L. M., \&Nicotra, A. B. 
(2015). Seed germination strategies: an evolutionary trajectory independent of vegetative functional traits. Frontiers in plant science, 6,731 .

Kamenetsky, R. (1996). Life cycle and morphological features of Allium L. species in connection with geographical distribution. Bocconea, 5, 251-257.

Kamenetsky, R., \& Gutterman, Y. (2000). Germination strategies of some Allium species of the subgenus Melanocrommuyum from arid zone of Central Asia. Journal of arid environments, 45(1), 61-71.

Kamenetsky, R., \& Rabinowitch, H. D. (2006). The genus Allium: A developmental and horticultural analysis. Horticultural ReviewsWestport Then New York-, 32, 329.

Kaya, E. (2014). Turkey's Geophytes, Volumes 1-23, Publ. No: 96 (Yalova, Turkey: Atatürk Central Horticultural Research Institute) (in Turkish).

Krussmann, G. (1981). The history of the modern garden rose. The Complete Book of Roses. Timber Press, Portland, OR, 67-105.

Leck, M. A., Parker, V. T., \& Simpson, R. L. (Eds.). (2008). Seedling ecology and evolution. Cambridge University Press.

Li, Q. Q., Zhou, S. D., He, X. J., Yu, Y., Zhang, Y. C., \& Wei, X. Q. (2010). Phylogeny and biogeography of Allium (Amaryllidaceae: Allieae) based on nuclear ribosomal internal transcribed spacer and chloroplast rps16 sequences, focusing on the inclusion of species endemic to China. Annals of botany, 106(5), 709-733.

Mahdi, H. S., Hussein, W. I., Salih, H. M., \& Youssef, S. M. A. A. (2018a). Effect of presowing treatments on seed germination of $P$. eurycarpa and $P$. khinjuk - Kurdistan region. Journal of Duhok University, 20(1), 105-113.
Mahdi, HS., Yaseen, DF., Hassan, HN., Selah-Alden, MT., Mahmood, MJ., Hameed, NA., Ahmed, GB., \& Youssef S. (2018b). Seed germination ecology and seedling emergence of sixteen tree species autumn sown. Journal of Duhok University 20 (1), 50-63.

Marcinek, B., Hetman, J., \&Kozak, D. (2013). Influence of cultivation method and bulbs planting depth on the growth and yielding of Tulips. Acta Scientiarum PolonorumHortorum Cultus, 12(5), 97-110.

Mattana, E., Daws, M. I., \&Bacchetta, G. (2010). Comparative germination ecology of the endemic Centranthus amazonum (Valerianaceae) and its widespread congener Centranthus ruber. Plant species biology, 25(3), 165-172.

Mittermeier, R. A., Gil, P. R., Hoffman, M., Pilgrim, J., Brooks, T., Mittermeier, C., ...\& Saligmann, P. A. (2004). Hotspots Revisited: Earth's Biologically Richest and Most Endangered Terrestrial Ecoregions Cemex. Mexico City.

Muhamed, H., Youssef, S., Mustafa, A., Suliman, H., Abdulkader, A., Mohammed, H., \& Michalet, R. (2019). Characterizing the natural regeneration of Pinus brutia Ten. in Duhok governorate, $\mathrm{N}$ Iraq. Journal of Forestry Research, 30(5): 1849-1857.

Nematollah, E., Maryam, H., \& Najmeh, Z. (2011). Optimizing seed germination threatened endemic species of the Persian shallot (Allium hirtifolium boiss.). African Journal of Agricultural Research, 6(22), 5133-5138.

Peel, M. C., Finlayson, B. L., \& McMahon, T. A. (2007). Updated world map of the KöppenGeiger climate classification. Hydrology and earth system sciences discussions, 4(2), 439473.

Phillips, N. (2010). Seed and bulb dormancy characteristics in new world Allium L. (Amaryllidaceae): a review. International Journal of Botany, 6, 228-234. 
Piotto, B., \& Di Noi, A. (2003). Seed propagation of Mediterranean trees and shrubs.

Pistrick, K. (1992). Phenological variability in the genus Allium L (No. RESEARCH). Institute of Plant Genetics and Crop Plant Research.

R Development Core Team (2019). R: A Language and Environment for Statistical Computing. R Foundation for Statistical Computing, Vienna, Austria. URL http://www.R-project.org/.

Razyfard, H., Zarre, S., Fritsch, R. M., \&Maroofi, H. (2011). Four new species of Allium (Alliaceae) from Iran. In Annales Botanici Fennici (Vol. 48, No. 4, pp. 352-361). Finnish Zoological and Botanical Publishing Board.

Roberts, E. H., \& Totterdell, S. (1981). Seed dormancy in Rumex species in response to environmental factors. Plant, Cell \& Environment, 4(2), 97-106.

Schulp, C. J., Thuiller, W., \&Verburg, P. H. (2014). Wild food in Europe: A synthesis of knowledge and data of terrestrial wild food as an ecosystem service. Ecological Economics, 105, 292-305.

Thompson, J. D. (2005). Plant evolution in the Mediterranean. Oxford University Press on Demand.

Véla, E., Youssef, S. \& Mahmood, A. 2017. Allium notabile. The IUCN Red List of Threatened Species 2017: e.T117540944A117540947.

Volaire, F. (2018). A unified framework of plant adaptive strategies to drought: Crossing scales and disciplines. Global change biology, 24(7), 2929-2938.
Wendelbo, P. and Stuart, D. 1985. Allium L. In: C.C. Townsend and E. Guest (eds), Flora of Iraq. Vol. 8: Monocotyledones, excluding Gramineae, pp. 1-140. Ministry of Agriculture \& Agrarian Reform, Baghdad.

Willis, C. G., Baskin, C. C., Baskin, J. M., Auld, J. R., Venable, D. L., Cavender- Bares, J., ... \& NESCent Germination Working Group. (2014). The evolution of seed dormancy: environmental cues, evolutionary hubs, and diversification of the seed plants. New Phytologist, 203(1), 300-309.

Winiarczyk, K., Skrzypczak, K., Jaroszuk-Scisel, J., \& Bocianowski, J. (2014). Investigations of the capacity and strength of seed germination in Allium victorialis L. Acta Societatis Botanicorum Poloniae, 83(3).

Youssef, S., Baumel, A., Véla, E., Juin, M., Dumas, E., Affre, L., \&Tatoni, T. (2011). Factors underlying the narrow distribution of the Mediterranean annual plant Arenaria provincialis (Caryophyllaceae). Folia Geobotanica, 46(4), 327-350.

Youssef, S., Mahmood, A., Hussein, W. \&Véla, E. (2017). Montagnes du Zagros, un paradis terrestre aux pratiques ethnobotaniques vivantes. La Garance voyageuse, 120: 41-45.

Youssef, S., Galalaey, A., Mahmood, A., Mahdi, H., \&Véla, E. (2019). Wild orchids of the Kurdistan Region areas: a scientific window on the unexpected nature of the North-Western Zagros. La Motte-d'Aigues (FR): Société Méditerrannéenne d'Orchidologie, $164 \mathrm{P}$. ISBN: 


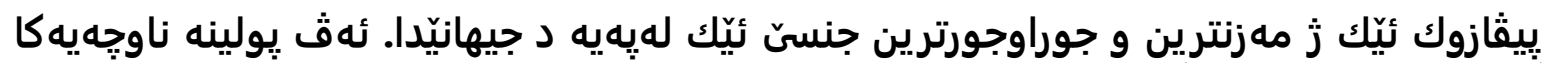
جوكرافيا مهزن بخوثه دكريت كو بشيَوريه

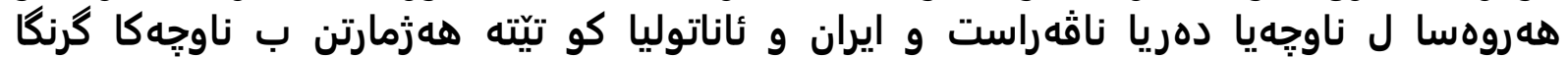

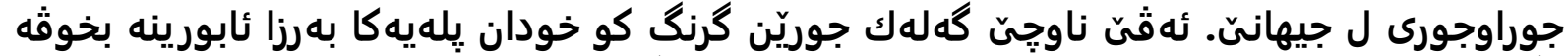

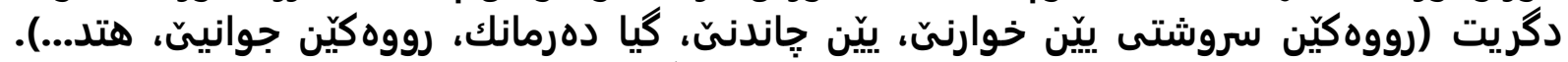

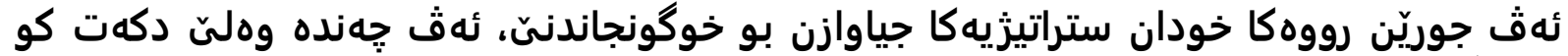

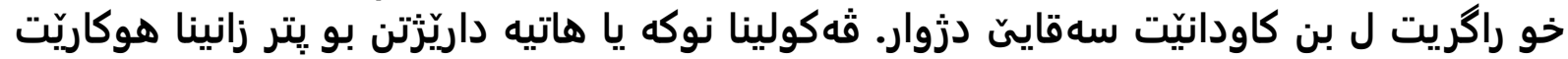

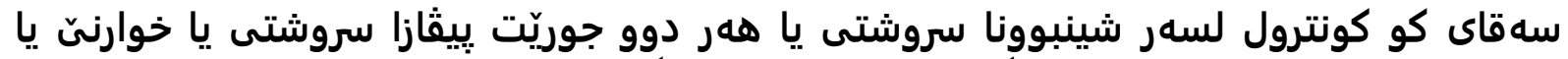

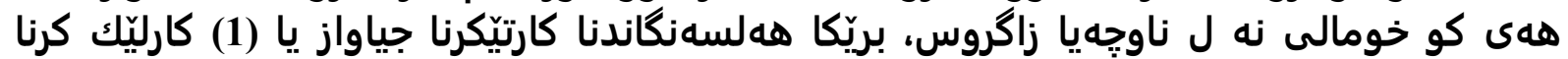

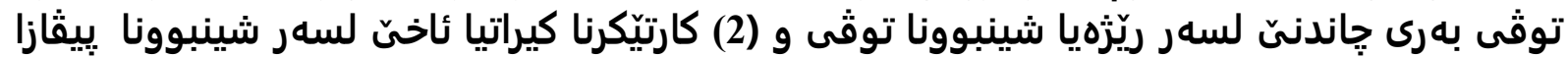

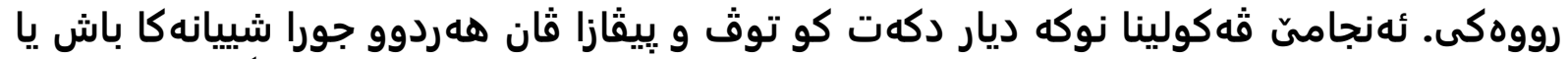

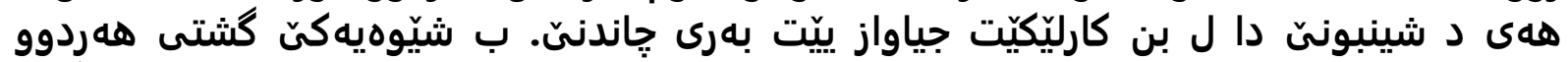

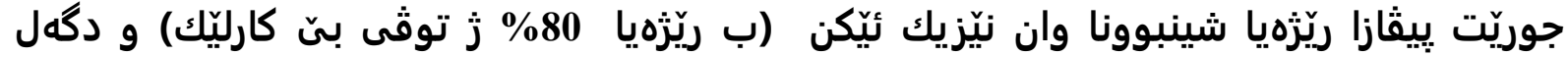

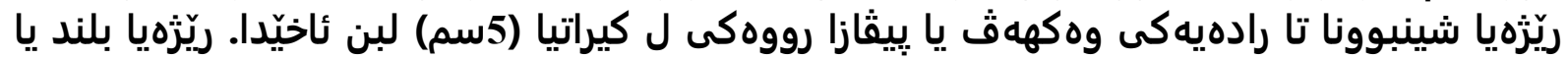

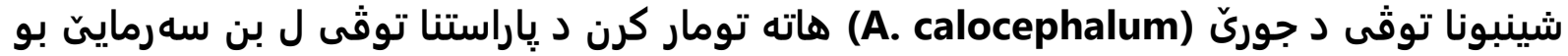

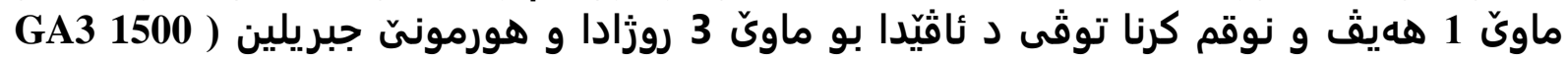

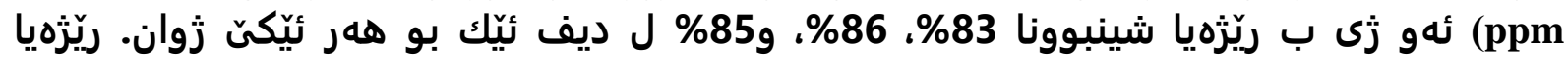

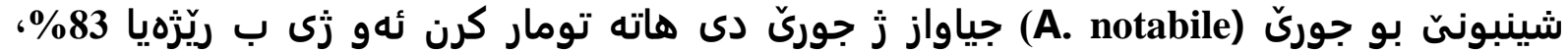

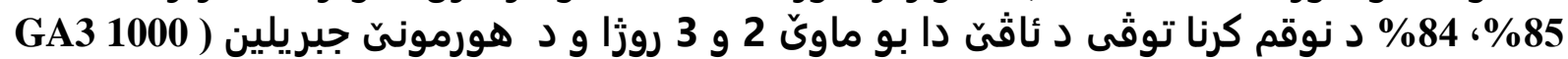

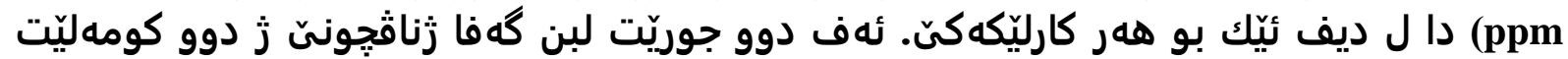

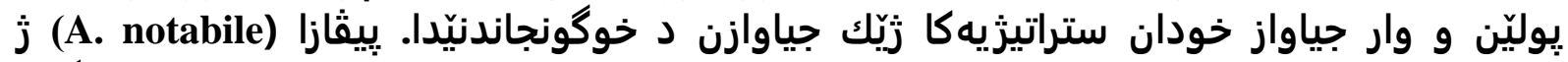

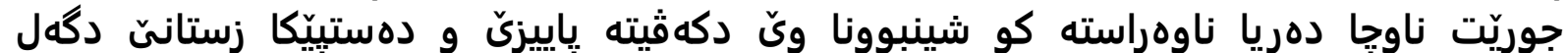

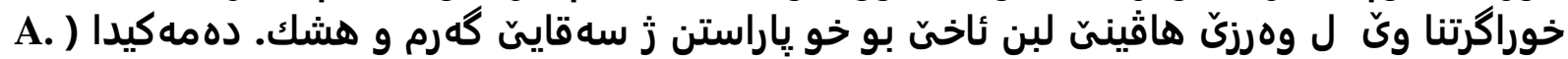
زستئ (calocephalum

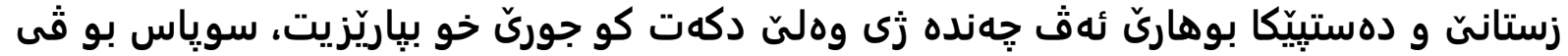

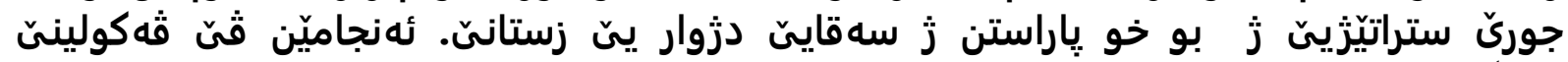

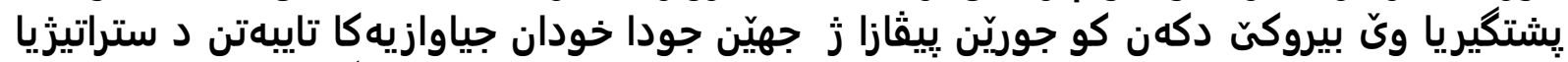

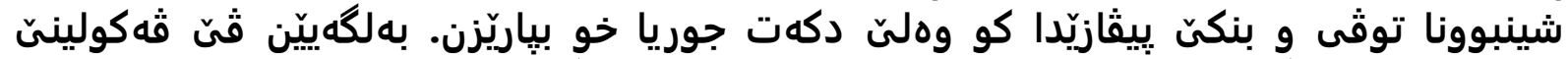

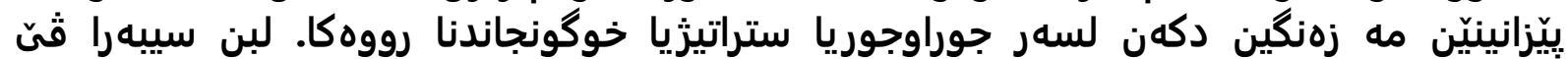

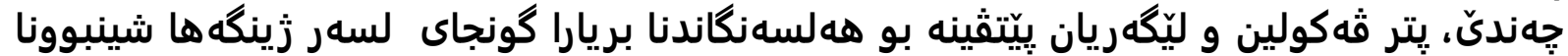

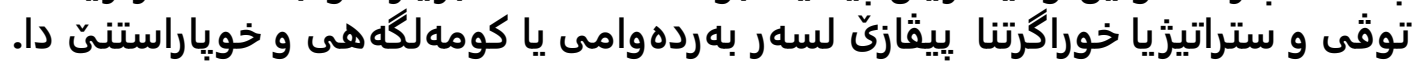

الخلاصة

الخعد الابصال أحد أكبر الأجناس الأحادية النسيلة وأكثرها تنوعًا في جميع أنحاء العالم. هذه ألها

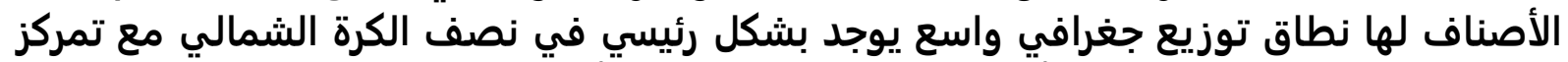

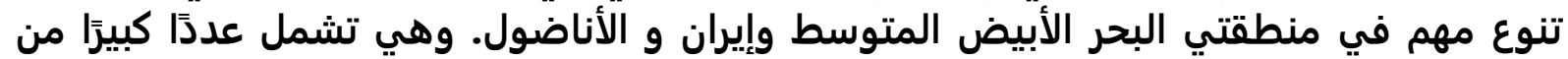

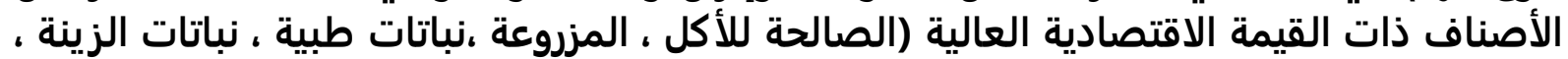

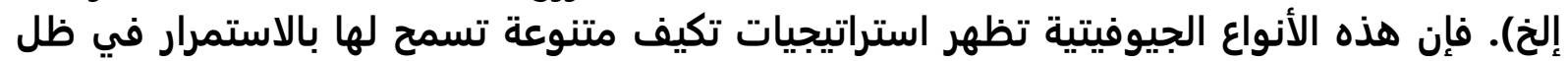
ظروف بيئية قاسية. وتظهر هذه الأنواع الجيولوجية الستراتية التياتيفيات تكيف متنوعة تسمح لها لهات 
بالاستمرار في ظل ظروف بيئية قاسيه. صممت هذه الدراسة لفهم العوامل البيئية التي تتحكم

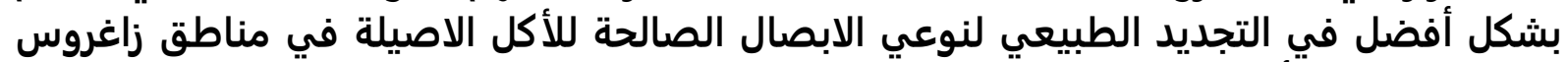

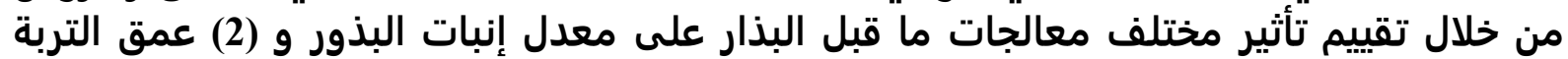

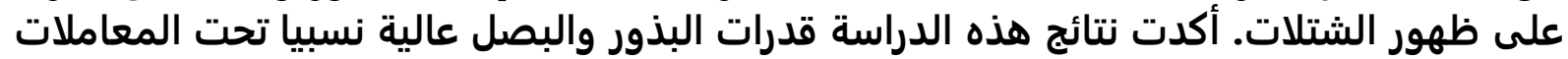

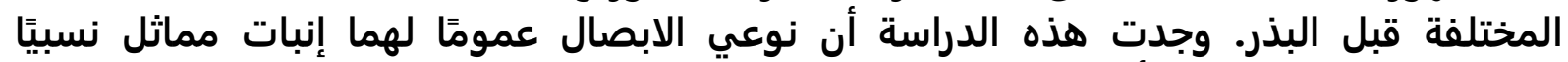

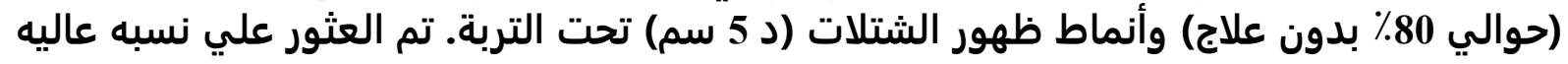

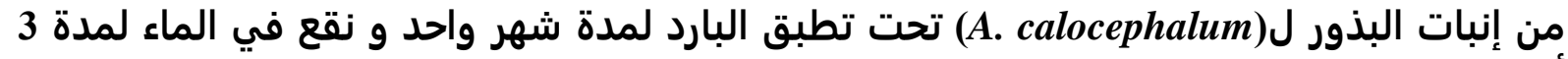

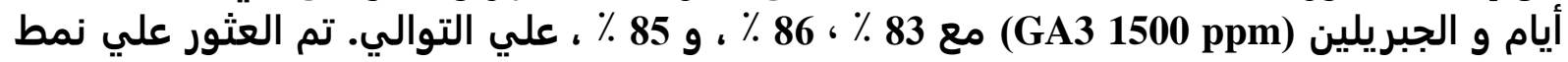

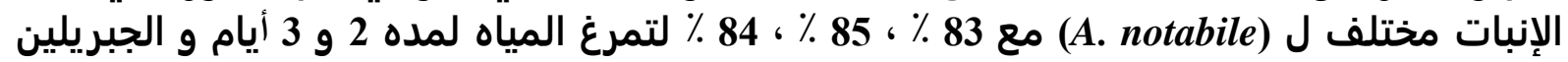

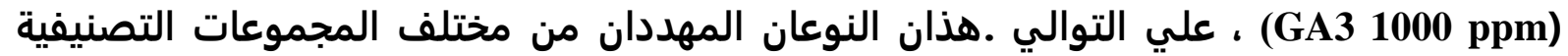

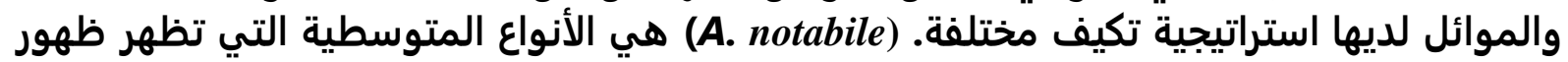

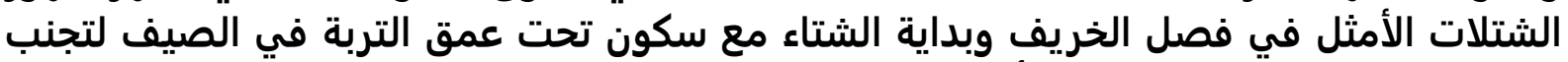

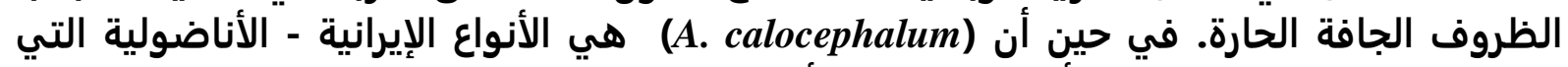

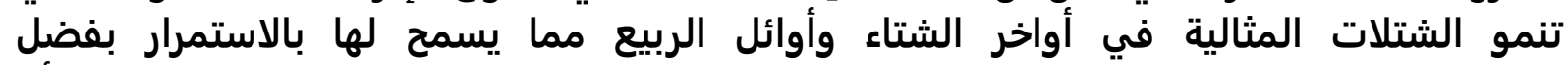

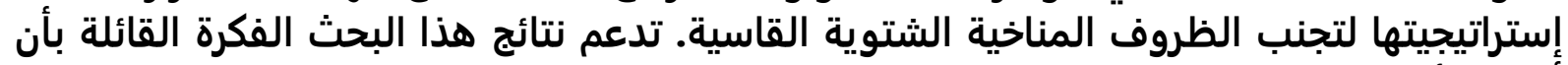

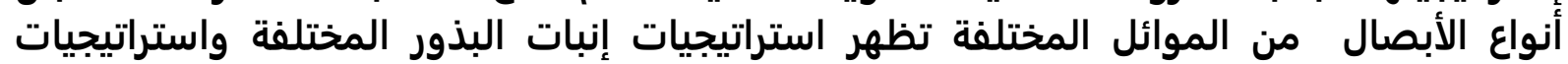

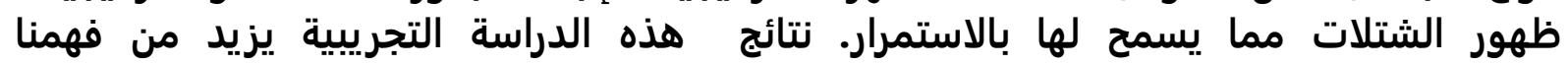

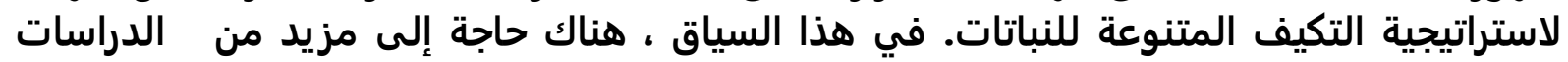

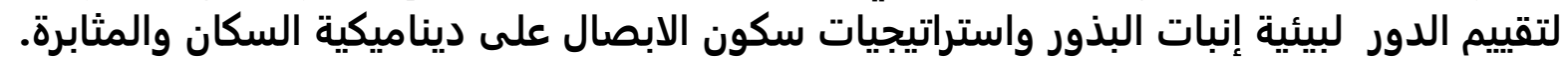

